\title{
Effect Of pH On Liquid-Phase Mass Transfer And Diffusivity Coefficient At Leachate Treatment Of Municipal Waste Landfill In Anaerobic Bioreactor
}

\author{
Abdul Kahar ${ }^{\mathrm{a}^{*}}$, IDAA Warmadewanthi ${ }^{\mathrm{b}}$ and Joni Hermana ${ }^{\mathrm{b}}$ \\ ${ }^{a}$ Department of Chemical Engineering, Faculty of Engineering, Mulawarman University, Gunung Kelua Jl. Sambaliung No. \\ 9, Samarinda 75119, Indonesia \\ ${ }^{b}$ Department of Environmental Engineering, Faculty of Civil Engineering and Planning, Institut Teknologi Sepuluh \\ Nopember, ITS Jl. AR Hakim Sukolilo, Surabaya 60111, Indonesia
}

Artikel histori :

Diterima 9 Juli 2018

Diterima dalam revisi 31 Juli 2018

Diterima 15 September 2018

Online 31 Oktober 2018

\begin{abstract}
ABSTRAK: Leachate is a liquid waste resulted from physical, biological and chemical decomposition of landfill waste. Leachate contains complex dissolved organic and inorganic substrate which are biodegradable and non-biodegradable. Anaerobic treatment principally utilizes anaerobic bacteria in order to degrade the dissolved organic substance into biogas. Anaerobic treatment is very sensitive towards the substrate concentration, temperature, and $\mathrm{pH}$. This research used anaerobic bioreactor with the volume of $160 \mathrm{~L}$, the ratio of the leachate:biogas is 70:30. Seeding and acclimatization steps were done, respectively for 10 days, leachate treatment was done in 21 days. Seeding, acclimatization, and leachate treatment were done on the $\mathrm{pH}$ ambience of 7.2 and 8.0 and ambient temperature. COD and VFA analysis were done every two days. The objective of this research is to decide the $\mathrm{pH}$ effect on the coefficient of liquid-phase mass transfer: $k_{L}$, and the diffusivity of the dissolved substance, $D_{L} . \mathrm{pH}$ affects the degradation of the concentration of dissolved organic substrate in the leachate. The higher the $\mathrm{pH}$ is, the higher the obtained VFA concentration is. VFA concentration is affected by $\mathrm{pH}$; however, it still considers the optimal $\mathrm{pH}$ condition of the substrate biodegradation. $\mathrm{pH}$ affects the average rate of mass transfer, $r_{k L}$ and diffusivity of the dissolved substance, $D_{L}$ in the anaerobic treatment of leachate. $\mathrm{pH}$ affect the concentration of dissolved organic substrate which subsequently influences the coefficient of liquid-phase mass transfer of the leachate, $k_{L}$ and the diffusivity of the dissolved substance, $D_{L}$. The higher the $\mathrm{pH}$ is, the more increasing the $k_{L}$ is and the more decreasing the $D_{L}$ is.
\end{abstract}

Keywords: anaerobic bioreactor; diffusivity leachate; mass transfer

\section{Introduction}

\subsection{Leachate}

Leachate is a liquid waste resulted from the influx of external water into the landfill waste. It either dissolves and washes away dissolved organic and inorganic materials or is suspended within the waste, including complex organic material resulted from physical, biological, and chemical decomposition (Kumaret al., 2013). Therefore, leachate becomes a complex mixture from dissolved organic material and inorganic contaminants. Leachate contains: VFA, LCFA, fulvic and humic compounds, ammonia-nitrogen, phosphate, sulfate, heavy metal, organic xenobiotic (XOCs); aromatic hydrocarbons, phenols, and chlorinated aliphatics, inorganic salts and microorganism (Christensen et al., 2001; Renou et al., 2008; Zainol et al., 2012; Hassan and Xie, 2014); and biorefactory contaminants (Tatsi et al., 2003). Therefore, leachate contains complex dissolved organic and inorganic substrates which are biodegradable and non-biodegradable (Christensen et al., 2001).
Such characteristics make leachate very dangerous for the environment with the contamination potential transcends some industrial waste (Zainol et al., 2012; Hassan and Xie, 2014). Characteristics and quality of leachate are influenced by: characteristics and composition of waste, type of soil covering the landfill, season, $\mathrm{pH}$ and humid; and the age of landfill (Zainol et al., 2012; Hassan and Xie, 2014). The variation of leachate composition depends on several factors, such as composition and age of landfill, design and operation and the condition of landfill, climate and hydrogeological condition, humidity, temperature, and level of stabilization (Renou et al., 2008). The mass transfer may occur during liquid phase, gas phase, or to both phases simultaneously. It may occur during multi-phase system or one phase system (Thibodeaux, 1996; Geankoplis, 2003). With concentration gradient, there will be a movement of mass transfer from higher concentrated area to the lower concentrated area. This movement is used so that the intensive contact occurs between the dissolved material and microorganism, that it enables more mass transfer (Geankoplis, 2003; Welty et al., 2007). In the case of

*Corresponding Author:

Email: a.kahar@ft.unmul.ac.id@mail.com 
complex organic substrate, which is generally expressed as Biological Oxygen Demand (BOD); Volatile Fatty Acid (VFA) or Chemical Oxygen Demand (COD), a part of substrate which is difficult to degrade (Zaiat et al., 2000; Christensen et al., 2001; Hassan and Xie, 2014).

The essential problem of the technical scale in the development of bioreactor is hydrodynamics, the phenomenon of mass transfer between phases, kinetics, and the thermal transfer (Leib et al., 2001). Despite the fact that it is not the main factor on bioprocess, mass transfer is crucial in anaerobic bioreactor (Leib et al., 2001; Doble, 2006; Benz, 2011). Many factors influencing the mass transfer on bioprocess such as: temperature, pressure, concentration, diffusivity, viscosity, density, $\mathrm{pH}$, fluid flow rate, bioreactor geometry, surface tension (Monit, 2009).

\subsection{Anaerobic Bioreactor}

Anaerobic treatment principally utilizes the anaerobic bacteria in order to degrade dissolved organic materials or soluble chemical oxygen demand (SCOD) to become biogas (Abdelgadir et al., 2014). The process of anaerobic decomposition degrades natural polymer, such as polysaccharides, proteins, nucleic acids, and lipids into methane and carbon dioxide. It occurs in gradual and parallel reaction. The efficiency of anaerobic bioreactor treatment is sensitive towards the composition of wastewater, temperature, and $\mathrm{pH}$ (Merlin et al., 2012).

Anaerobic treatment of organic material is a complex and specific biochemical reaction. Biodegradation of dissolved organic material undergoes reaction stages: hydrolysis, acidogenesis, acetogenesis and methanogenesis that happen simultaneously, either in serial or parallel ways (Zinatizadeh et al., 2006; van Lier et al., 2008; Deublein and Steinhauser, 2008; Appels et al., 2008; Abdelgadir et al., 2014). Bacteria that plays the role on the four stages works specifically and has mutual dependence (Hossain et al., 2009).

Hydrolysis is a liquifaction of organic materials using extra-celular enzyme produced by hydrolytic bacteria (Zinatizadeh et al., 2006; Deublein and Steinhauser, 2008; Appels et al., 2008). Celulolytic bacteria holds the role in hydrolisis stage, works in the $\mathrm{pH}$ rate of 6-7. In this process, the likelihood of $\mathrm{pH}$ degradation may happen due to the formation of organic acids. Hydrolisis depends on the parameter such as: particle size, $\mathrm{pH}$, enzyme production, diffusion and adsorption of enzyme on the waste particle that undergoes decomposition process (Ziemiński and Frac, 2012), the substrate concentration and temperature (Gerber and Roland, 2008). Another research reported that the rate of hydrolysis constant depends on $\mathrm{pH}$ but not coefficient with the total and concentration of VFA (Veeken et al., 2000). And the best $\mathrm{pH}$ range to reach maximum biogas result in anaerobic bioreactor is 6.5-7.5 (Liu et al., 2008; Khalid et al., 2011) and 6.8-7.2 (Ward et al., 2008).

Acidogenesis is a step of the recast of organic materials resulted from hydrolysis to become amino acid, simple sugar and VFA, including format acid, acetic, propionic, butyric, lactic, succinic, ethanol, and $\mathrm{CO}_{2}, \mathrm{H}_{2}, \mathrm{NH}_{3}, \mathrm{H}_{2} \mathrm{~S}$ by acid-forming bacteria (van Lier et al., 2008; Ziemiński and Frac, 2012). For batch system experiment, the range of $\mathrm{pH}$ on stage thermophilic acidogenesis is 6-7 (Park et al., 2008). VFA is an intermediate product which is very important in anaerobic treatment (Appels et al., 2008). Acetogenesis is a stage of forming acetic compound, carbondioxyde and hydrogen (Ziemiński and Frac, 2012). It is reported that methanogenesis in anaerobic bioreactor is efficient on the $\mathrm{pH}$ of 6.5-8.2 (Lee et al., 2009), while hydrolysis and acidogenesis respectively on the $\mathrm{pH}$ of 5.5 and 6.5 (Kim et al., 2009). The last step in anaerobic biodegradation is methanogenesis. Most methanogens bacteria is mesophilic with the range of temperature between $28-42^{\circ} \mathrm{C}$ and thermophilic temperature with the range of $55-72^{\circ} \mathrm{C}$ (Ziemiński and Frac, 2012). Optimum methanogens bacteria on the $\mathrm{pH}$ range of 7.2-8.0 (Suryawanshi et al., 2013).

\subsection{Mass Transfer and Diffusion of Dissolved Material}

The coefficient of liquid-phase mass transfer is a function of liquid physical characteristic and the liquid superficial velocity (Zaiat et al., 2000; Abdelgadir et al., 2014). If the liquid-phase mass transfer becomes the limitation of the whole process rate, then $k_{L}$ can be estimated with Equation 1 (Zaiat et al., 2000; Cho and Young, 2001).

$$
N_{L}=k_{L}\left(S_{b}-S_{i}\right)
$$

Where $N_{L}$ is the flux of liquid-phase mass transfer, $\left(\mathrm{mg} / \mathrm{cm}^{2} . \mathrm{h}\right) ; k_{L}$ is the coefficient of liquid-phase mass transfer; $S_{b}$ is the substrate concentration on the bulk liquid, (mg COD/L); and $S_{i}$ is the substrate concentration on the solid-liquid interface, (mg COD/L).

Mass transfer depends on the diffusion of dissolved materials and the variables controlling the character of fluid flow such as; flow rate, viscosity, density, and a linear dimension. Diffusion based on empirical modification reported by Wilke-Chang (Geankoplis, 2003), where the solution diffusion can be calculated using Equation 2.

$$
D_{L}=7,4 x 10^{-8} \frac{\left(\psi_{B} \cdot M_{B}\right)^{1 / 2} T}{\mu_{L} \cdot V_{A}^{0,6}}
$$

Where, $D_{L}$ is liquid-phase diffusion of the dissolved materials and the solvent, $\mathrm{cm}^{2} / \mathrm{s} ; T$ is temperature, $K ; \mu_{L}$ is viscosity of the solution, $\mathrm{cP} ; V_{A}$ is the molar volume of the dissolved material in normal boiled point, $\mathrm{cm}^{3} / \mathrm{gmol} ; \Psi_{B}$ is the parameter of solvent association (water $=2.6$ ) and $M_{B}$ is the weight of solution molecule $(18 \mathrm{~g} / \mathrm{gmol})$.

Several studies reported that bioreactor failures or deficient performance due to $\mathrm{pH}$ degradation is caused by the accumulation VFA within the system of anaerobic treatment (Visser et al., 1993; Fabián dan Gordon, 1999; Poh and Chong, 2009; Thabathaba'i et al., 2011). The increase of VFA concentration in batch system bioreactor 
gives different influence towards hydrolysis, acidogenesis, and methanogenesis stages (Appels et al., 2008). The high VFA concentration will obstruct hydrolysis, acidogenesis, and methanogeneis that the adequate process of mass transfer and microorganism seeding become important things in anaerobic bioreactor (Vabilin et al., 2002).

The objectives of this research is to decide the $\mathrm{pH}$ influence towards the coefficient of liquid-phase mass transfer; $k_{L}$, and the diffusion of dissolved material, $D_{L}$ on the leachate treatment in anaerobic bioreactor.

\section{Method}

Leachate used was from Sambutan Landfill, Samarinda, East Borneo, Indonesia. The anaerobic bioreactor used was featured with heater, leachate recirculation pump, leachate recirculation flowmeter, manometer, leachate entrance inlet, biogas thermometer, pressure gauge, leachate thermomeer, sampling port, leachate recirculation entrance faucet, leachate recirculation exit faucet and leachate effluent faucet. The type of this research is pilot scale experiment with semi-batch system.

This research uses anaerobic bioreactor with the total volume $\pm 160 \mathrm{~L}$. After doing characterization and analysis of leachate quality, subsequently the designing of anaerobic bioreactor with the design according to the need of the research was done. Then the test of leakage and calibration from the system of anaerobic bioreactor was done.

Seeding and acclimatization were done, respectively for 10 days. Then it was continued by anaerobic treatment for 21 days. Seeding and acclimatization were done in the anaerobic bioreactor on the ambient temperature with $\mathrm{pH}$ variation: ambient, 7.2 and 8.0 , where the ratio of leachate volume: biogas was 70:30. Microorganism used was from cow rumen and leachate with the ratio of $1: 3$ and filtered for the extract. Analysis and parameter test of COD and VFA were done once in two days. The process of leachate treatment was stopped if the decreasing percentage of COD (COD removal) reached 60-80\%.

\section{Result and Discussion}

\subsection{Results}

The condition of seeding and acclimatization was done on $\mathrm{pH}$ ambient. On seeding, the leachate temperature started from 27.4-29 ${ }^{\circ} \mathrm{C}$, biogas temperature of $26-27.5{ }^{\circ} \mathrm{C}, \mathrm{pH}$ decreased from 7.5-7.3, and the biogas pressure started to increase on the $9^{\text {th }}$ day, for 1-1.5 $\mathrm{mm} \mathrm{H}_{2} \mathrm{O}$. Meanwhile on acclimatization, the leachate temperature started for 28.2-28.5 ${ }^{\circ} \mathrm{C}$, biogas temperature of 27-27.9 ${ }^{\circ} \mathrm{C}, \mathrm{pH}$ increased from 7.2-7.7, and biogas pressure increased from 4-21 $\mathrm{mm} \mathrm{H}_{2} \mathrm{O}$, with the average value of BOD/COD 0.58.

The condition of seeding and acclimatization was done on $\mathrm{pH}$ of 7.2. On seeding, the leachate temperature started from $28.2-29{ }^{\circ} \mathrm{C}$, biogas temperature of $27.5-28.5^{\circ} \mathrm{C}$, and the biogas pressure started to increase on the $6^{\text {th }}$ day, with the up and down fluctuation between 1 up to $5 \mathrm{~mm}_{2} \mathrm{O}$. Meanwhile on acclimatization, the leachate temperature started for $27-27.5^{\circ} \mathrm{C}$, biogas temperature of $26-27.5^{\circ} \mathrm{C}$, and biogas pressure increased from 7-29 $\mathrm{mm} \mathrm{H}_{2} \mathrm{O}$, with the average value of BOD/COD 0.70 .

The condition of seeding and acclimatization was done on $\mathrm{pH}$ of 8.0. On seeding, the leachate temperature started from $27-28.5^{\circ} \mathrm{C}$, biogas temperature of $26-27.9{ }^{\circ} \mathrm{C}$, and the biogas pressure started to increase on the $8^{\text {th }}$ day, with the up and down fluctuation between 1-2 mm $\mathrm{H}_{2} \mathrm{O}$. Meanwhile on acclimatization, the leachate temperature started for $27-28.5^{\circ} \mathrm{C}$, biogas temperature of $26-27.9{ }^{\circ} \mathrm{C}$, and biogas pressure increased from 3-17 $\mathrm{mm} \mathrm{H}_{2} \mathrm{O}$, with the average value of BOD/COD 0.65 .

\subsection{Mass Transfer Rate, $r_{k L}$ and Diffusion Rate of Dissolved Material, $r_{D L}$}

On $\mathrm{pH}$ ambient, the average mass transfer rate per day was the lowest of $0.00407 \mathrm{mg} / \mathrm{L}$.day and the highest on the $27^{\text {th }}$ day which was $0.14134 \mathrm{mg} / \mathrm{L}$.day. The rate of dissolved material diffusion ranged between $5.57442 \times 10^{-5}$ $1.40034 \times 10^{-4} \mathrm{~cm}^{2} / \mathrm{s}$. On the $\mathrm{pH}$ of 7.2 , the average rate of mass transfer per day was the lowest of $0.00227 \mathrm{mg} / \mathrm{L}$.day and the highest on the $25^{\text {th }}$ day was $0.16953 \mathrm{mg} / \mathrm{L}$.day. The rate of dissolved material diffusion initially decreased and then increased, with the range between $5.96009 \times 10^{-5}$ $1.44715 \times 10^{-4} \mathrm{~cm}^{2} / \mathrm{s}$. Meanwhile on the leachate treatment within anaerobic bioreactor with the $\mathrm{pH}$ of 8.0 , the average rate of mass transfer per day was the lowest of 0.02957 $\mathrm{mg} / \mathrm{L}$.day and the highest on the $37^{\text {th }}$ day was 0.13090 $\mathrm{mg} / \mathrm{L}$.day. The rate of dissolved material diffusion went up and down, with the range between $5.54146 \times 10^{-5}$ $1.2416 \times 10^{-4} \mathrm{~cm}^{2} / \mathrm{s}$.

A research about $\mathrm{pH}$ influence on two-phased anaerobic bioreactor reported that acidogenic bioreactor preserved on the $\mathrm{pH}$ of 6.0-7.0; resulted in the decrease of SCOD from $6000 \mathrm{mg} / \mathrm{L}$ to $1000-1500 \mathrm{mg} / \mathrm{L}$, that the efficiency of COD removal increased from $50 \%$ to $80 \%$. And the methane production of $0.32 \mathrm{~m}^{3} \mathrm{CH}_{4} / \mathrm{kg}$ COD removed with methane contents on the methanogenic bioreactor of $80-90 \%$. Meanwhile, without the $\mathrm{pH}$ control, the $\mathrm{pH}$ condition on acidogenic bioreactor increased up to 8.2; the acid conversion decreased yet the COD degradation was almost similar to the $\mathrm{pH}$ controlled on 6.0-7.0. Only without the $\mathrm{pH}$ control, methane contents from methanogenic bioreactor increases more for $90 \%$ (Jung et al., 2000).

\subsection{Discussion}

\subsection{1. pH}

$\mathrm{pH}$ in seeding and acclimatization steps, went up and down from the lowest of 6.3 and increased up to 7.9. As seen in Figure 1, where seeding and acclimatization steps were done on the first day until the $20^{\text {th }}$ day. It can be seen that seeding step on $\mathrm{pH}$ ambient ranged between 6.2 up to 7.8 . Meanwhile, acclimatization step on $\mathrm{pH}$ ambient ranged between 6.3 up to 8.0 . 


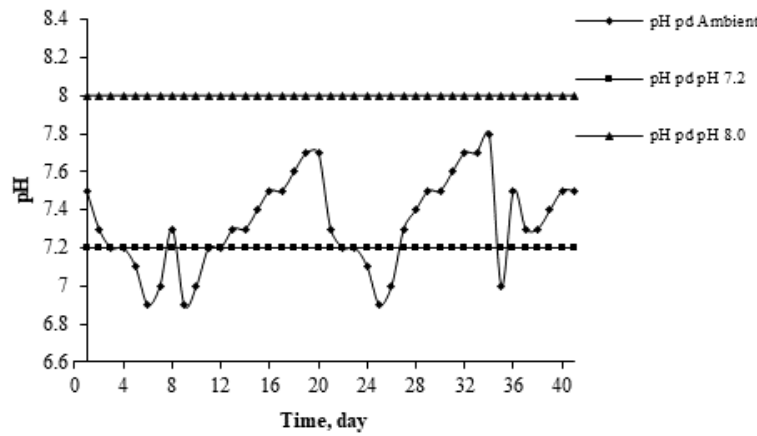

Figure 1. $\mathrm{pH}$ on multiple variations

$\mathrm{pH}$ is one of important parameters on anaerobic treatment because methanogenic bacteria is very sensitive towards the change of $\mathrm{pH}$. Methane-forming bacteria live well on neutral to a little alkali condition. $\mathrm{pH}$ in bioreactor is directly dependent on the retention time (Kigozi et al., 2014).

$\mathrm{pH}$ on both stages, seeding-acclimatization steps and anaerobic treatment, showed the difference of $\mathrm{pH}$ range. Where $\mathrm{pH}$ of seeding-acclimatization was on a little acid $\mathrm{pH}$ while $\mathrm{pH}$ of anaerobic treatment was on a little alkali $\mathrm{pH}$. It occurred due to the fact that biodegradation stage involved hydrolysis bacteria which produced extra-cellular enzyme (Abdelgadir et al., 2014). This group of cellulolytic bacteria optimally played the role on the $\mathrm{pH}$ ranging between 6-7. Dihydrolisis protein became amino acid by the protease functioning as exo-enzyme. Hydrolysis lipid became glycerol and fat acid. Hydrolysis hydrocarbon became glucose and other simple sugars. Hydrolysis was done by facultative anaerobic bacteria through exo-enzyme (Wiesmann et al., 2007). In this process, the likelihood of $\mathrm{pH}$ decrease may happen due to the formation of organic acids.

In initial stage, a large number of VFA is produced by acid-forming bacteria, $\mathrm{pH}$ in bioreactor may decrease up to below 5. This condition can obstruct or stop the process within bioreactor. Methanogenic bacteria is very sensitive towards the change of $\mathrm{pH}$ and cannot develop on the $\mathrm{pH}$ below 6.5 despite the fact that the process can still run within $\mathrm{pH}$ range between 6.0-8.0 (Kigozi et al., 2014).

Meanwhile, on anaerobic treatment stage, where anaerobic biodegradation that played the role was methanogenesis bacteria; hydrogenophilic or hydrogenotrophic, that formed methane from $\mathrm{CO}_{2}$ and $\mathrm{H}_{2}$ and methanogens acetoclastic or acetotrophic, resulting in methane by acetate decarbonization manner (Sekiguchi dan Kamagata, 2004). The group of methanogens bacteria utilized the result from three biogas. Methanogens bacteria is optimally mesophilic within the temperature range of 28 $42{ }^{\circ} \mathrm{C}$ (Ziemiński and Frac, 2012) and optimum on the $\mathrm{pH}$ range of $7.2-8.0$ (Suryawanshi et al., 2013).

\subsubsection{COD and BOD}

The indicator of microorganism success in biodegradation is the decrease of substrate concentration (COD and BOD) in the leachate, as shown in Figure 2.
The substrate concentration (COD and BOD) on acclimatization stage, $11^{\text {th }}$ day up to $21^{\text {st }}$ day, decreased, as shown on figure 4.10 and 4.11 . The minimal decrease of COD was $40.42 \%$ and maximal of $75.07 \%$. Meanwhile the minimal decrease of BOD was $41.97 \%$ and maximal of $72.78 \%$.

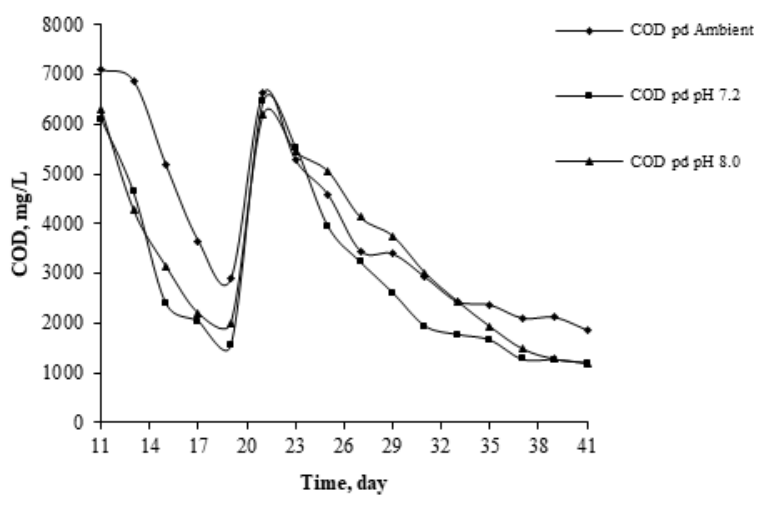

a.

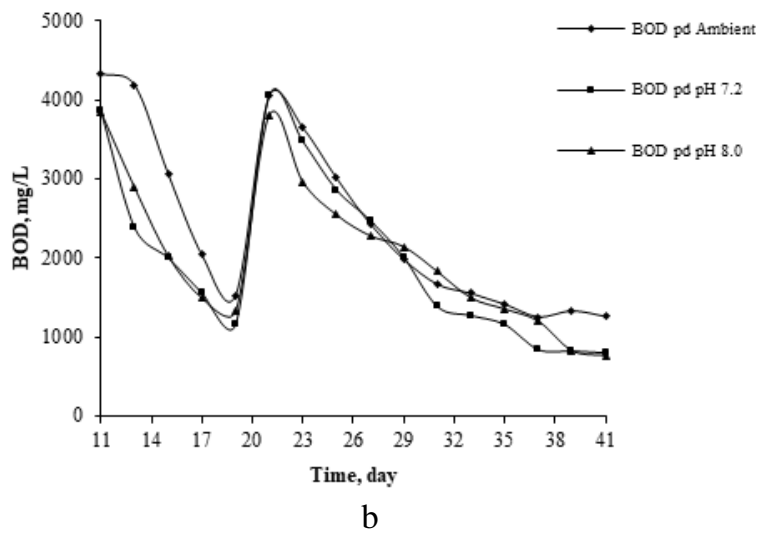

Figure 2. a. COD and b. BOD on $\mathrm{pH}$ variations

The decrease of COD and BOD on acclimatization stage was caused by the decrease of dissolved substrate concentration utilized by microorganism to grow, reproduce, and adapt within the leachate. Therefore, in this stage, the hydrolysis undissolved complex organic molecules become simple molecules dissolved in the leachate. It indicates that the growth of bacteria goes well. It can also be seen that the value of biodegradability ratio $\mathrm{BOD} / \mathrm{COD}$ ranges between 0.43-0.70. The process of anaerobic treatment is effective enough for leachate with the high BOD:COD ratio resulted from the landfill initial stage (Li et al., 2010).

After the acclimatization stage entered the anaerobic treatment stage, leachate was added on the $21^{\text {st }}$ day, COD and BOD increased again, as seen in figure 2. Such increase occurred due to the addition of organic and inorganic materials dissolved in the leachate within the bioreactor. Therefore, COD and BOD increased due to the addition of substrate concentration to the leachate.

The $\mathrm{pH}$ also affects the decrease of substrate concentration in anaerobic treatment stage, the $21^{\text {st }}$ until $41^{\text {st }}$ days. The percentage of COD decrease on $\mathrm{pH}$ ambient, 
$\mathrm{pH} 7.2$ and $\mathrm{pH} 8.0$ respectively were $71.84 \%, 81.43 \%$ and $80.55 \%$. Therefore, COD removal on $\mathrm{pH} 7.2>\mathrm{pH} 8.0>\mathrm{pH}$ ambient. Meanwhile BOD removal obtained ranged between $68.91 \%$ and $80.29 \%$. With average COD and BOD removal respectively were $77.94 \%$ and $76.37 \%$.

On overall stages, seeding-acclimatization and anaerobic treatment, the COD and BOD removal were on pH $7.2>$ pH $8.0>$ pH ambient. .The bigger COD reduction was, the bigger the organic material degraded to organic acids. Organic acids were subsequently converted to methane gas. Therefore, the bigger reduction of COD was, the bigger the rate of methane gas formation was.

\subsubsection{VFAs}

VFA is an intermediate product (Appels et al., 2008) that will be converted on acetogenesis stage to become acetate acid (Gerardi, 2003; Ganidi et al., 2009), $\mathrm{CO}_{2}$ and $\mathrm{H}_{2}$ (Ziemiński and Frac, 2012). The VFA concentration is determined as a parameter in order to figure out how far the acidogenesis and acetogenesis stages go. Where VFA concentration becomes one of the good parameters to monitor in deciding the stability of anaerobic bioreactor.

The higher the $\mathrm{pH}$ is, the higher the obtained VFA concentration is. The VFA concentration is influenced by $\mathrm{pH}$. On $\mathrm{pH}$ influence, it is obtained that the VFA concentration ranges between 83.33-370.63 mg/L. However, it still considers the optimum $\mathrm{pH}$ condition of the microorganism involved in such biodegradation. Where
VFA and $\mathrm{pH}$ ambient $>\mathrm{pH} 7.2>\mathrm{pH} 8.0$ as seen in Figure 3.

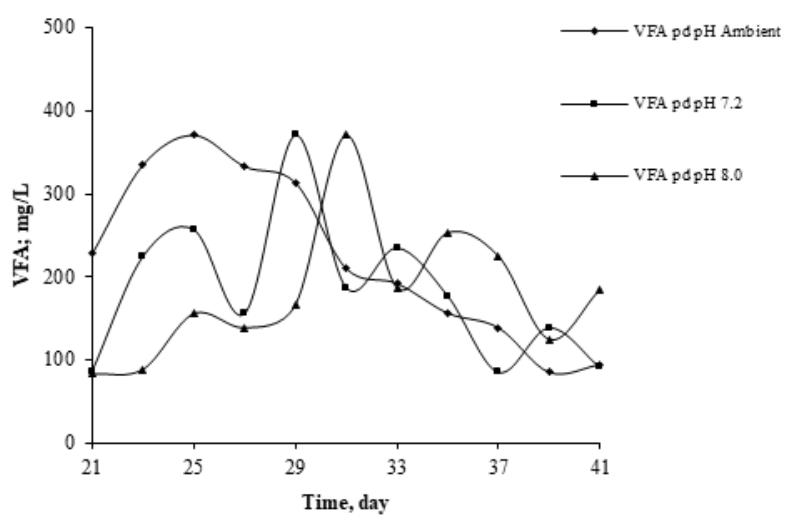

Figure 3. VFA from $\mathrm{pH}$ variation

As seen in figure 4, in the initial treatment, VFA increase is accompanied by the decrease of substrate concentration (COD and BOD). As time goes by, the bigger the $\mathrm{COD}$ and $\mathrm{BOD}$ removal are, the more decreasing VFA is. It is an undeniable fact that the exponential increase of VFA decreases again; it shows that the dependence of VFA towards the limited substrate concentration in the leachate (Reid et al., 1991). It can also be seen that the highest VFA concentration in all operation condition was on the $25^{\text {th }}-31^{\text {st }}$ days.

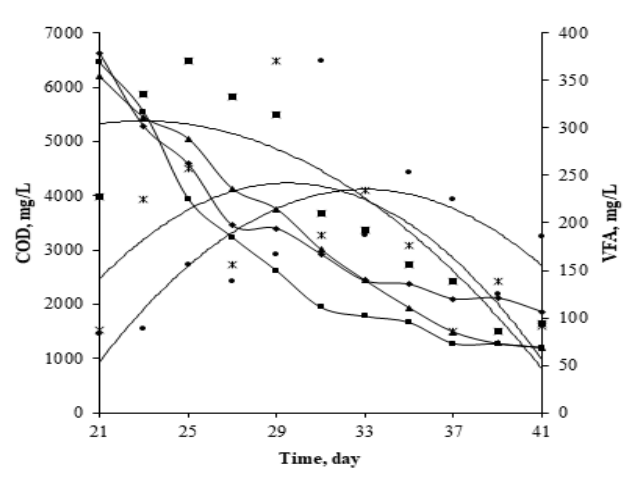

$$
\begin{aligned}
& - \text { COD pd Ambient } \\
& - \text { COD pd pH } 7.2 \\
& -\quad \text { COD pd pH } 8.0 \\
& \approx \quad \text { VFA pd Ambient } \\
& \star \quad \text { VFA pd pH } 7.2 \\
& -\quad \text { VFA pd pH } 8.0 \\
& \text { Poly. (VFA pd } \\
& \text { Ambient) } \\
& \text { Poly. (VFA pd pH } \\
& \text { 7.2) (VFA pd pH } \\
& \text { Poly. (VFA po) }
\end{aligned}
$$

a.

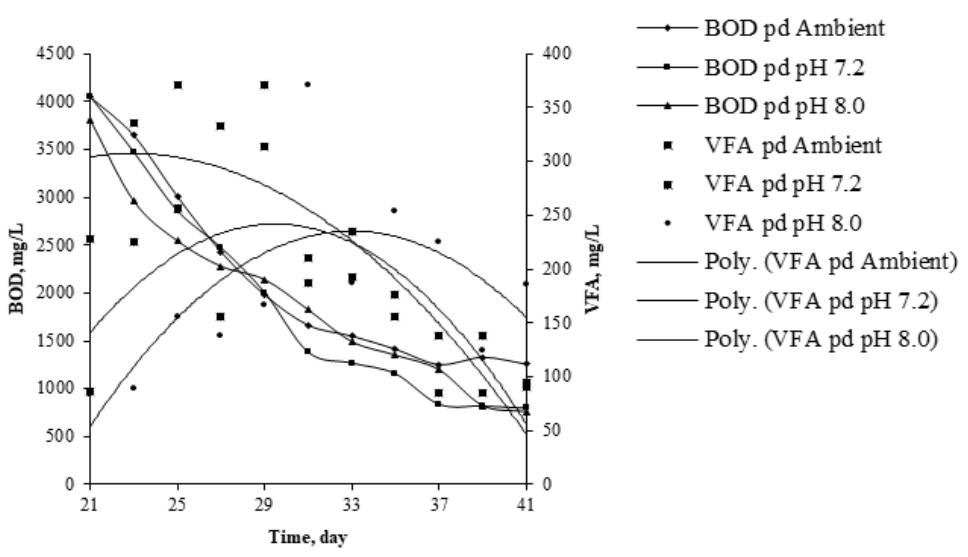

b.

Figure 4. a. COD vs VFA and b. BOD vs. VFA 
The VFA accumulation within anaerobic bioreactor represented imbalance between acid produced and consumed by bacteria. If the bioreactor overloads and the content of VFA concentration is high, bigger than what the methane-producing bacteria consumes (slow-growers), then the biogas production will increase. This increase potentially improves the foaming in anaerobic bioreactor (Baber, 2005). The higher the biodegraded COD is, the higher VFA concentration is. The more decreasing the substrate concentration is, the more decreasing the VFA concentration is. It is in line with the statement that the higher reduced substrate concentration is, the bigger the biodegraded dissolved organic material to become organic acids is. This VFA is subsequently converted into methane gas. Therefore, if the decrease of COD gets bigger, then the rate of biogas formation becomes higher.

\subsubsection{Liquid-Phase Mass Transfer and Diffusion of Dissolved Material}

The mass transfer and dissolved material diffusion in the leachate also depends on the change of dissolved substrate concentration within the leachate. The average of mass transfer per day is the number dissolved material substrate biodegraded in each day. COD degradation is accompanied by the increase of mass transfer rate, average $r_{k L}$ per day. Diffusion of dissolved material, $D_{L}$ decreases by the increase of the pressure. As seen in figure 5, figure 6 , and figure 7.

On $\mathrm{pH}$ ambient, it is obtained that the average lowest $r_{k L}$ per day is $0.00407 \mathrm{mg} / \mathrm{L}$.day and the highest on the $27^{\text {th }}$ day is $0.14134 \mathrm{mg} / \mathrm{L}$.day. $r_{D L}$ of the dissolved material ranges between $5.57442 \times 10^{-5}-1.40034 \times 10^{-4} \mathrm{~cm}^{2} / \mathrm{s}$. On $\mathrm{pH}$ of 7.2, the average lowest $r_{k L}$ per day is $0.00227 \mathrm{mg} / \mathrm{L}$.day and the highest on the $25^{\text {th }}$ day is $0.16953 \mathrm{mg} / \mathrm{L}$.day. The coefficient of liquid-phase mass transfer is $0.08400 \mathrm{~cm} / \mathrm{s}$. $r_{D L}$ of the dissolved material initially decreases and then increases, with the range between $5.96009 \times 10^{-5}-1.44715$ $\mathrm{x} 10^{-4} \mathrm{~cm}^{2} / \mathrm{s}$. Meanwhile with the $\mathrm{pH}$ of 8.0 , the obtained lowest average $r_{k L}$ per day is $0.02958 \mathrm{mg} / \mathrm{L}$.day and the highest on the $37^{\text {th }}$ day is $0.13090 \mathrm{mg} / \mathrm{L}$. day. The coefficient of liquid-phase mass transfer is $0.09200 \mathrm{~cm} / \mathrm{s}$. $r_{D L}$ of the dissolved material initially decreases and then increases, with the range between $5.54146 \times 10^{-5}-1.2416$ x $10^{-4} \mathrm{~cm}^{2} / \mathrm{s}$.

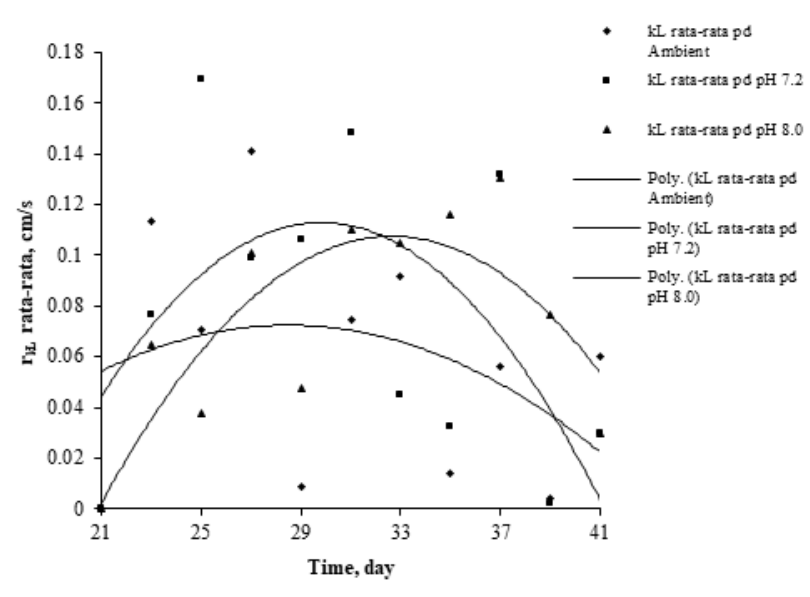

a.

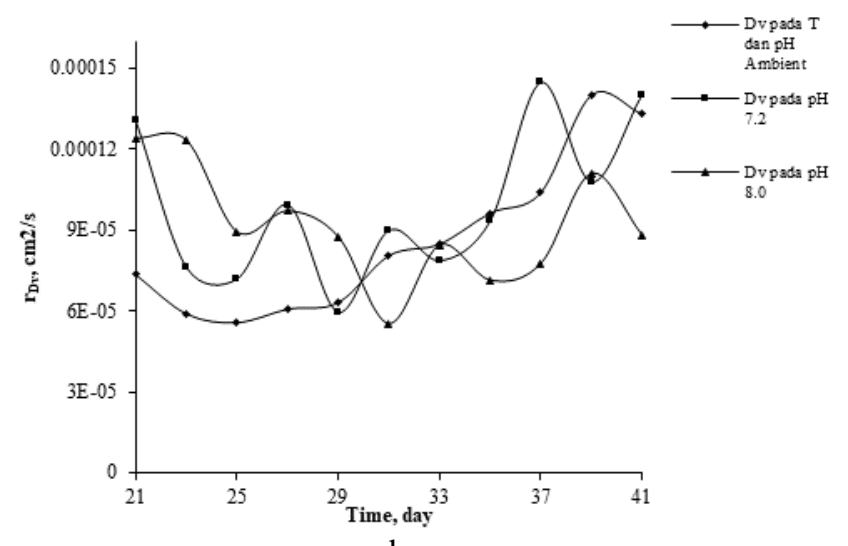

b.

Figure 5. $r_{k L}$ and $r_{D L}$ on $\mathrm{pH}$ variations
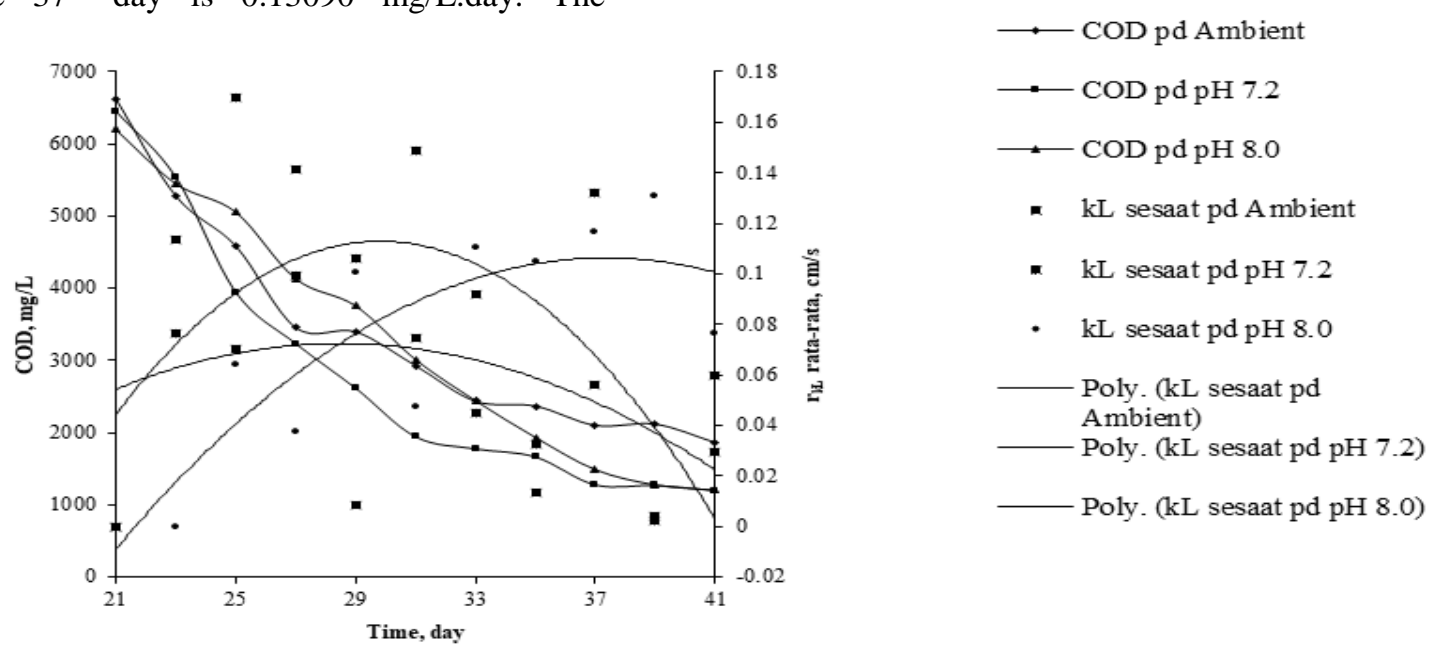


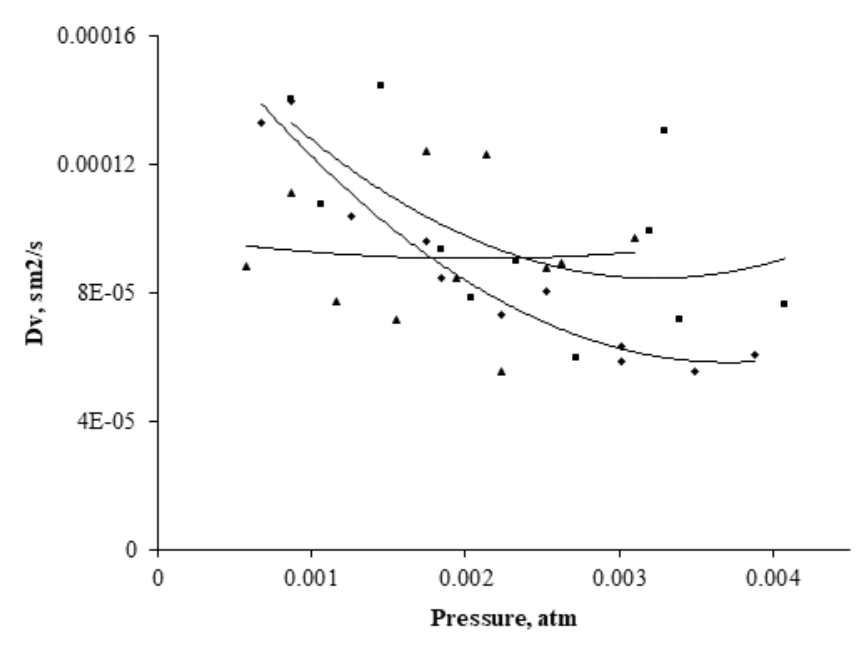

Tekanan vs Difusivitas pd pH Ambient

- Tekanan vs difusivitas pd $\mathrm{pH}$ 7.2

Tekanan vs difusivitas pd $\mathrm{pH}$ 8.0

Poly. (Tekanan vs Difusivitas pd pH Ambient)

Poly. (T ekanan vs difusivitas pd pH 7.2)

Poly. (T ekanan vs difusivitas pd pH 8.0)

b.

Figure 6. a. COD vs $\mathrm{r}_{\mathrm{kL}}$ on $\mathrm{pH}$ variation; b. Diffusivity vs Biogas Pressure on $\mathrm{pH}$ variation

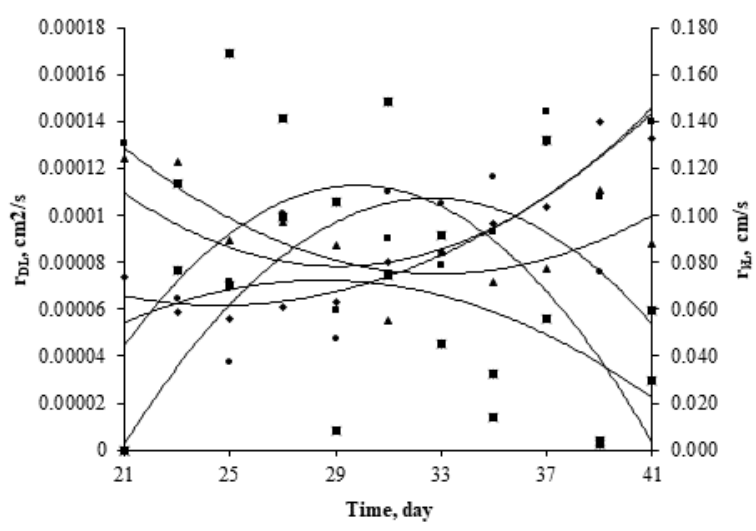

- Dv pd Ambient

- $\quad$ Dv pd pH 7.2

- Dv pd pH 8.0

- $\mathrm{kL}$ pd Ambient

- $\mathrm{kL} \mathrm{pd} \mathrm{pH} 7.2$

- $\quad \mathrm{kL}$ pd pH 8.0

Poly. (Dv pd Ambient)

- Poly. (Dv pd pH 7.2)

Poly. (Dv pd pH 8.0)

Poly. (kL pd Ambient)

- Poly. (kL pd pH 7.2)

Poly. (kL pd pH 8.0)

Figure 7. $r_{D L}$ vs $r_{k L}$ on $\mathrm{pH}$ variation

The $k_{L}$ and $D_{L}$ of leachate treatment within the anaerobic bioreactor done on $\mathrm{pH}$ ambient, $\mathrm{pH} 7.2$ and $\mathrm{pH}$ 8.0. Where the coefficient of liquid-phase mass transfer increases from $0.056-0.092 \mathrm{~cm} / \mathrm{s}$, while the diffusivity of dissolved materials decreases from $4.10 \times 10^{-6}$ to $1.10 \mathrm{x}$ $10^{-6} \mathrm{~cm}^{2} / \mathrm{s}$, as seen from Table 1 .

Table 1. Liquid-phase Mass Transfer Coefficient, $k_{L}$, and Coefficient of Dissolved Materials Diffusion; $D_{L}$

\begin{tabular}{lcc}
\hline Treatment, $\mathbf{p H}$ & $\mathbf{k}_{\boldsymbol{L}}, \mathbf{c m} / \mathbf{s}$ & $\mathbf{D}_{\boldsymbol{L}}, \mathbf{c m}^{\mathbf{2}} / \mathbf{s}$ \\
\hline Ambient & 0.056 & $4.10^{-06}$ \\
7.2 & 0.084 & $2.10^{-06}$ \\
8.0 & 0.092 & $1.10^{-06}$ \\
\hline
\end{tabular}

On the treatment of $\mathrm{pH}$ variation, it can be seen that the higher $\mathrm{pH}$ is, the more increasing $k_{L}$ is and the more increasing the $\mathrm{D}_{L}$ is. $\mathrm{k}_{\mathrm{L}} \mathrm{pH} 8.0>k_{L} \mathrm{pH} 7.2>k_{L} \mathrm{pH}$ ambient. Meanwhile $D_{L} \mathrm{pH}$ ambient $>D_{L} \mathrm{pH} 7.2>D_{L} \mathrm{pH} 8.0$, as seen in Figure 8.

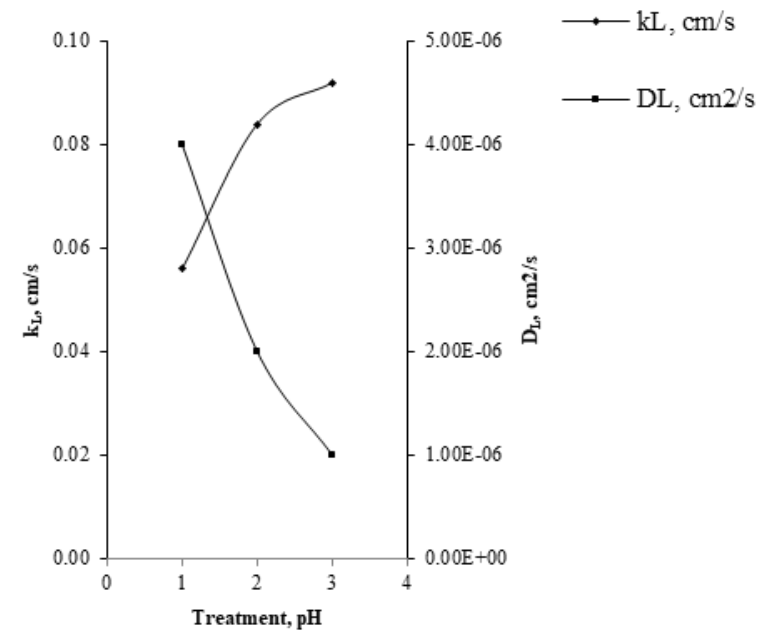

Figure 8. $D_{L}$ vs $k_{L}$ on $\mathrm{pH}$ variations 
Table 2. Research on Mass Transfer

\begin{tabular}{|c|c|c|c|c|c|c|c|c|}
\hline Bioreactor & Wastewater & $\mathbf{V}_{\mathrm{R}}, \mathbf{L}$ & HRT(days) & $\begin{array}{l}\text { Temp. } \\
\left({ }^{\circ} \mathrm{C}\right)\end{array}$ & $\begin{array}{l}\mathrm{COD}_{\text {Inf. }} \\
(\mathrm{mg} / \mathrm{L})\end{array}$ & $\begin{array}{l}\text { COD }_{\text {Rem. }} \\
(\%)\end{array}$ & $\begin{array}{l}\text { Mass Transfer } \\
\text { Coefficient, } k_{L}\end{array}$ & References \\
\hline \multirow{2}{*}{$\begin{array}{l}\text { HAIB } \\
\text { (pilot-scale) }\end{array}$} & $\begin{array}{l}\text { Glucose-based } \\
\text { synthetic substrate }\end{array}$ & \multirow{2}{*}{237} & $8 \mathrm{~h}$ & 30 & $2.090-41$ & 98 & $3.40 .10^{-2} \mathrm{~cm} / \mathrm{h}$ & \multirow{2}{*}{$\begin{array}{l}\text { Zaiatet al., } \\
2000 \\
\text { Zaiatet al., } \\
2000\end{array}$} \\
\hline & Domestic Sewage & & $8 \mathrm{~h}$ & 30 & $341-71$ & 79.2 & $2.23 .10^{-1} \mathrm{~cm} / \mathrm{h}$ & \\
\hline $\begin{array}{l}\text { Two-stage } \\
\text { Anaerobic } \\
\text { Filter }\end{array}$ & $\begin{array}{l}\text { Brewery } \\
\text { wastewater }\end{array}$ & $\begin{array}{l}7.45 \\
\text { and } \\
6.55\end{array}$ & $0.5-6 \mathrm{~d}$ & 35 & $\begin{array}{l}1500-2500 \\
\text { (OLR 0.5-20 } \\
\text { g SCOD/L.d }\end{array}$ & 98.2 & $1.4-2.2 \mathrm{~d}^{-1}$ & $\begin{array}{l}\text { Cho and } \\
\text { Young, } \\
2001\end{array}$ \\
\hline $\begin{array}{l}\text { Fixed-Bed } \\
\text { ASBR }\end{array}$ & $\begin{array}{l}\text { Synthetic } \\
\text { Wastewater } \\
\text { (Polyurethane } \\
\text { Foam) }\end{array}$ & 1.2 & $8 \mathrm{~h}$ & 30 & $500-68$ & $72-87$ & $1.98-1.85 \mathrm{~h}^{-1}$ & $\begin{array}{l}\text { Ramos et } \\
\text { al., } 2003\end{array}$ \\
\hline UASB & $\begin{array}{l}\text { Synthetic } \\
\text { Wastewater } \\
\text { (phenol) }\end{array}$ & 3.78 & $0.97-1.03 \mathrm{~d}$ & 35 & $\begin{array}{c}10.53-12.61 \\
\mathrm{~kg} \mathrm{COD} / \mathrm{m}^{3} . \mathrm{d}\end{array}$ & $\begin{array}{l}99.3- \\
96.3\end{array}$ & $\begin{array}{l}19.2 \mathrm{mg} \\
\text { phenol/L }\end{array}$ & $\begin{array}{l}\text { Chou and } \\
\text { Huang, } \\
2005\end{array}$ \\
\hline SASBR & $\begin{array}{l}\text { Synthetic } \\
\text { Wastewater } \\
\text { (Polyurethane } \\
\text { Foam) }\end{array}$ & 5 & & 30 & $285-333$ & $84-89$ & $0.48-0.60 \mathrm{~h}^{-1}$ & $\begin{array}{l}\text { Cubas et al., } \\
2007\end{array}$ \\
\hline $\begin{array}{l}\text { Anaerobic } \\
\text { Batch } \\
\text { Bioreactor } \\
\text { (pilot-scale) }\end{array}$ & Leachate & 160 & $1 \mathrm{~d}$ & $\begin{array}{l}\text { Ambient } \\
(27-30)\end{array}$ & $6200-6625.4$ & $\begin{array}{l}71.84- \\
81.43\end{array}$ & $\begin{array}{c}0.056,0.084 \\
\text { and } 0.092 \mathrm{~cm} / \mathrm{s}\end{array}$ & $\begin{array}{l}\text { This } \\
\text { research }\end{array}$ \\
\hline $\begin{array}{l}\text { Anno } \\
\text { HAIB } \\
\text { UASE } \\
\text { ASBR } \\
\text { SASB }\end{array}$ & $\begin{array}{l}\text { rizontal-Flow Anaerob } \\
\text { flow Anaerobic Sludg } \\
\text { aerobic sequencing bat } \\
\text { tirred Anaerobic Sequ }\end{array}$ & $\begin{array}{l}\text { mmobili } \\
\text { ed Reac } \\
\text { Reactor } \\
\text { ng Batc }\end{array}$ & $\begin{array}{l}\text { Biomass } \\
\text { actor }\end{array}$ & & & & & \\
\hline
\end{tabular}

The large number of wastewater used in the research on mass transfer is synthetic wastewater (Zaiat et al., 2000; Ramos et al., 2003; Chou and Huang, 2005; Cubas et al., 2007) and on laboratory scale (Cho and Young, 2001; Ramos et al., 2003; Chou and Huang, 2005; Cubas et al., 2007). The research done by Souza et al. (2014) aims at finding out the density and viscosity of leachate on different temperatures. Meanwhile, the research done by Vavilin et al. (2002), on anaerobic bioreactor of solid waste on the influence of leachate recirculation and $\mathrm{pH}$ aims at analyzing the balance between hydrolysis rate/organic polymer acidogenesis and methanogenesis. The comparison of the research done in this research is shown in Table 2.

\section{Conclusion}

The $\mathrm{pH}$ affects the decrease of concentration of dissolved organic substrate (COD and BOD) of the leachate. The higher the $\mathrm{pH}$ is, the higher the obtained VFA concentration is. VFA concentration is influenced by $\mathrm{pH}$, but still considering the optimum $\mathrm{pH}$ condition of the biodegraded substrate. $\mathrm{pH}$ affects the average mass transfer rate, $r_{k L}$ on the anaerobic treatment of leachate. $\mathrm{pH}$ affects the concentration of dissolved organic substrate which subsequently influences the coefficient of liquid-phase mass transfer of leachate, $k_{L}$ and diffusivity of dissolved material, $D_{L}$. The higher the $\mathrm{pH}$ is, the more increasing the $k_{L}$ is and the more decreasing the $D_{L}$ is. The $k_{L} \mathrm{pH} 8.0>k_{L}$
pH $7.2>k_{L} \mathrm{pH}$ ambient. Meanwhile, $D_{L} \mathrm{pH}$ ambient $>D_{L}$ pH $7.2>D_{L}$ pH 8.0. The coefficient of liquid-phase mass transfer increases from $0.056-0.092 \mathrm{~cm} / \mathrm{s}$, while the diffusivity of dissolved material decreases from $4.10 \times 10^{-6}$ to $1.10 \times 10^{-6} \mathrm{~cm}^{2} / \mathrm{s}$.

\section{Acknowledgement}

We thank the Directorate of Research and Community Service (DP2M) Dikti that have funded this research, with the letter of agreement No: No: 416/UN17.41/KL/2017.

\section{Nomenclature}

$N_{L}$ is flux of liquid-phase mass transfer, $\left(\mathrm{mg} / \mathrm{cm}^{2} . \mathrm{h}\right)$

$k_{L}$ is coefficient of liquid-phase mass transfer

$S_{b}$ is substrate concentration on bulk liquid, (mg COD/L)

$\mathrm{Si}$ is substrate concentration on solid-liquid interface, (mg $\mathrm{COD} / \mathrm{L})$

$D_{L}$ is liquid-phase diffusion of dissolved material and solvent, $\left(\mathrm{cm}^{2} / \mathrm{s}\right)$

$T$ is temperature, $(\mathrm{K})$

$\mu_{L}$ is viscosity of solvent, (cP)

$V_{A}$ is molar volume of dissolved material in normal boiling point, $\left(\mathrm{cm}^{3} / \mathrm{gmol}\right)$

$\Psi_{B}$ is the parameter of solvent association (air $=2.6$ )

$M_{B}$ is the weight of solvent molecule $(18 \mathrm{~g} / \mathrm{gmol})$ 


\section{References}

Abdelgadir, A., Xiaoguang Chen, Jianshe Liu, XuehuiXie, Jian Zhang, Kai Zhang, Heng Wang, and Na Liu., 2014. Characteristics, Process Parameters, and Inner Components of Anaerobic Bioreactors. BioMed Research International Volume 2014, Article ID 841573, http://dx.doi.org/10.1155/2014/841573, pp. 1-10.

Appels, L., Jan Baeyens., Jan Degre`ve., Raf Dewil., 2008. Principles and potential of the anaerobic digestion of waste-activated sludge. Progress in Energy and Combustion Science 34 (2008) 755-781.

Barber, W.P., 2005. Anaerobic Digester Foaming: Causes and Solutions. Water 21 (FEB), 45-49.

Benz, G.T., 2011. Bioreactor Design for Chemical Engineers. American Institute of Chemical Engineers (AIChE), August 2011. www.aiche.org/cep. p.21-26.

Cho, Y.T., and Young, J.C., 2001. Prediction of Gas Production and COD Removal of Two-Stage Cyclic Anaerobic Filters by Mass Transfer Models. Environ. Eng. Res. Vol. 6, No. 4, 2001, pp. 211-222.

Chou, H.H., and Ju-Sheng Huang., 2005. Role of Mass Transfer Resistance in Overall Substrate Removal Rate in Upflow Anaerobic Sludge Bed Reactors. Journal of Environmental Engineering, Vol. 131, No. 4, April 1, 2005. ISSN 0733-9372/2005/4548-556 DOI:10.1061/(ASCE)0733-9372(2005) 131:4(548)

Christensen, T.H., Peter Kjeldsen, Poul L. Bjerg, Dorthe L. Jensen, Jette B. Christensen, Anders Baun, HansJorgen Albrechtsen, Gorm Heron., 2001. Review: Biogeochemistry of Landfill Leachate Plumes. Apllied Geochemistry 16 (2001) 659-718.

Cubas, S.A., E. Foresti, J.A.D. Rodrigues, S.M. Ratusznei, M. Zaiat., 2007. Effects of solid-phase mass transfer on the performance of a stirred anaerobic sequencing batch reactor containing immobilized biomass. Bioresource Technology 98 (2007), p. 1411-1417.

Deublein, D., and Steinhauser, A., 2008. Biogas from waste and renewable resources. Weinheim, Willey-VCH Verlag GmbH \& Co. KGaA.

Doble, M., 2006. Avoid the Pitfalls of Bioprocess Development. Bioprocessing, August 2006. www.cepmagazine.org. p.34-41.

Ganidi, N., Sean Tyrrel., Elise Cartmell., 2009. Anaerobic Digestion Foaming Causes - A review. Bioresource Technology, Volume 100, Issue 23, December 2009, p. 5546-5554.

Geankoplis, C.J., 2003. Transport Processes and Separation Process Principles. Fourth Edition. International Edirion Pearson Prantice Hall, NJ.

Gerardi, M.H., 2003. The microbiology of anaerobic Digesters. 1st ed. Somerset NJ: Wiley.

Gerber, M., and Roland Span., 2008. An Analysis of Available Mathematical Models for Anaerobic
Digestion of Organic Substances for Production of Biogas. International Gas Union Research Conference IGRC, Paris.

Hassan, M., and Xie, B., 2014. Use of aged refuse-based bioreactor/biofilter for landfill leachate treatment. Appl. Microbiol. Biotechnol (2014) 98:65436553, DOI 10.1007/s00253-014-5813-5

Hossain, Sk.M., N. Anantharaman, and Manas Das., 2009. Anaerobis Biogas Generation from Sugar Industry Wastewater in Three-phase Fluidized-Bed Bioreactor. Indian Journal of Chemical Technology, Vol. 16, January 2009, pp.58-64.

Khalid, A., Muhammad Arshad, Muzammil Anjum, Tariq Mahmood, and Lorna Dawson, 2011. Review: The anaerobic digestion of solid organic waste. Waste Management 31 (2011).1737-1744.

Kigozi, R., A. Aboyade and E. Muzenda., 2014. Biogas Production Using the Organic Fraction of Municipal Solid Waste as Feedstock. Int'l Journal of Research in Chemical, Metallurgical and Civil Engg. (IJRCMCE) Vol. 1, Issue 1(2014) ISSN 2349-1442 EISSN 2349-1450, p. 107-114, http://dx.doi.org/10.15242/IJRCMCE.E1113563.

Kim, J., Park, C., Kim, T.H., Lee, M., Kim, S., Kim, S.W., Lee, J., 2003. Effects of various pretreatments for enhanced anaerobic digestion with waste activated sludge. J.Biosci. Bioeng. 95, p.271-275.

Kumar, S., DhruvKatoria and Gaurav Singh. 2013. Leachate Treatment Technologies. International Journal of Environmental Engineering and Management. ISSN 2231-1319, Volume 4, Number 5 (2013), pp. 439-444.

Lee, D.H., Behera, S.K., Kim, J., Park, H.S., 2009. Methane production potential of leachate generated from Korean food waste recycling facilities: a lab scale study. Waste Manage. 29, p.876-882.

Lee, W.S., Adeline Seak May Chua, Hak Koon Yeoh, Gek Cheng Ngoh., 2014. A review of the production and applications of waste-derived volatile fatty acids. Chemical Engineering Journal 235 (2014) 83-99.

Leib, T.M., Carmo J. Pereira, and John Villadsen., 2001. Bioreactors: a chemical engineering perspective. Chemical Engineering Science 56 (2001) 54855497.

Li, W., Zhou, Q., and Hua1, T., 2010. Review ArticleRemoval of Organic Matter from Landfill Leachate by Advanced Oxidation Processes: A Review. International Journal of Chemical Engineering Vol. 2010, Article ID 270532, 10 pages doi:10.1155/2010/270532.

Liu, C., Yuan, X., Zeng, G., Li, W., Li, J., 2008. Prediction of methane yield at optimum $\mathrm{pH}$ for anaerobic digestion of organic fraction of municipal solid waste. Bioresour. Technol. 99, p.882-888.

Liu, H., J. Wang, X. Liu, B. Fu, J. Chen, H. Yu., 2012. Acidogenic fermentation of proteinaceous sewage 
sludge: effect of pH. Water Res. 46 (2012) 799807.

Merlin, G., François Kohler., Maele Bouvier., Thierry Lissolo., Hervé Boileau., 2012. Importance of heat transfer in an anaerobic digestion plant in a continental climate context. Bioresource Technology 124 (2012), p.59-67.

Monit, M., 2009. Bioprocess Design: The Geogas Project: Bioremediation of geothermal gases and SCP production with HOX/SOX bacteria. A Master's thesis done at RES the School for Renewable Energy Science. in affiliation with University of Iceland \& the University of Akureyri Akureyri, February 2009. www.res.is.

Park, Y., Tsuno, H., Hidaka, T., Cheon, J., 2008. Evaluation of operational parameters in thermophilic acid fermentation of kitchen waste. J. Mater. Cycl. Waste Manage. 10, p.46-52.

Poh, P.E., Chong, M.F., 2009. Development of anaerobic digestion methods for palm oil mill effluent (POME) treatment. Bioresour. Technol. 100, p. 19.

Ramos, A.C.T., Suzana M. Ratusznei, José A.D. Rodrigues, Marcelo Zaiat, 2003. Mass transfer improvement of a fixed-bed anaerobic sequencing batch reactor with liquid-phase circulation. Interciencia, vol. 28, no. 4, April, 2003, 03781844/03/04/214-06, pp. 214-219.

Renou, S., J.G. Givaudan, S. Poulain, F. Dirassouyan and P. Moulin., 2008. Landfill leachate treatment: Review and opportunity. Journal of Hazardous Materials $150 \quad$ (2008), 0304-3894, doi:10.1016/j.jhazmat.2007.09.077, p. 468-493.

Souza, M.A.B.B., Oliveira, M.B., Araújo, A.S.F., de Castro J.A., 2014. Analyze of the Density and Viscosity of Landfill Leachate in Different Temperatures. American Journal of Environmental Engineering 2014, 4(4): 71-74. DOI: 10.5923/j.ajee.20140404.01

Suryawanshi, P.C., Chaudhari A.B., Bhardwaj S., and Yeole T.Y., 2013. Operating Procedures for Efficient Anaerobic Digester Operation. Research Journal of Animal, Veterinary and Fishery Sciences, ISSN 2320 - 6535, Vol. 1(2), March (2013), 12-15.

Tabatabaei, M., Alawi Sulaiman, Ali M. Nikbakht., NorjanYusof., GhasemNajafpour. 2011. Influential Parameters on Biomethane Generation in Anaerobic Wastewater Treatment Plants. ISBN: 978-953-307-372-9, InTech, Available from: http://www.intechopen.com

Tatsi, A.A., A.I. Zouboulis, K.A. Matis, P. Samaras., 2003. Coagulation-flocculation pretreatment of sanitary landfill leachates. Chemosphere 53 (2003) 737744. doi:10.1016/S0045-6535(03)00513-7.

Thibodeaux, L.J., 1996. Environmental Chemodynamics: Movement of Chemical in Air, Water, and Soil.
Second Edition. Awiley-Interscience Publication. John Wiley \& Sons, Inc. NY.

Van Lier, J.B., Mahmoud, N., and Zeeman, G., 2008. Anaerobic Wastewater Treatment: Biological Wastewater Treatment: Principles Modelling and Design. Edited by M. Henze, M.C.M. van Loosdrecht, G.A. Ekama, and D. Brdjanovic. ISBN: 9781843391883. IWA Publishing, London, UK. p. 401-441.

Vavilin, V.A., Rytov, S.V., Lokshina. L.Y., Pavlostathis, S.G., Barlaz, M.A., 2002. Distributed model of solid waste digestion-effects of leachate recirculation and $\mathrm{pH}$ adjustment. Biotechnol Bioeng 2002;81:66-73.

Veeken, A., Sergey Kalyuzhnyi, Heijo Scharff, and Bert Hamelers., 2000. Effect of $\mathrm{pH}$ and VFA on hydrolysis of organic solid waste. Journal of Environmental Engineering, Vol. 126, No. 12, December, 2000, ISSN 0733-9372/00/0012, p.1076-1081.

Ward, A.J., Hobbs, P.J., Holliman, P.J., Jones, D.L., 2008. Optimization of the anaerobic digestion of agricultural resources. Bioresour. Technol. 99, p.7928-7940.

Welty, J.R., Charles E. Wicks, Robert E. Wilson, and Gregory L. Rorrer. 2007. Fundamentals of Momentum, Heat, and Mass Transfer. $5^{\text {th }}$ Edition. John Wiley \& Sons, Inc.

Wiesmann, U., In Su Choi., Eva-Maria Dombrowski., 2007. Fundamentals ofBiological Wastewater Treatment. WILEY-VCH Verlag GmbH \& Co. KGaA, Weinheim, ISBN: 978-3-527-31219-1.

Zaiat, M., Jose' Alberto Domingues Rodrigues, Eugenio Foresti., 2000. External and internal mass transfer effects in an anaerobic fixed-bed reactor for wastewater treatment. Process Biochemistry 35 (2000), p.943-949.

Zainol, N.A.,Hamidi Abdul Aziz andMohdSuffianYusoff., 2012. Characterization of Leachate from Kuala Sepetang and Kulim Landfills: A Comparative Study. Energy and Environment Research; EISSN 1927-0577, Vol. 2, No. 2; 2012, doi:10.5539/eer.v2n2p45, p.45-52.

Ziemiński, K., and Frąc, M., 2012. Review: Methane Fermentation Process As Anaerobic Digestion Of Biomass: Transformations, Stages And Microorganisms. African Journal of Biotechnology, ISSN 1684-5315, Vol. 11(18), pp. 4127-4139.

Zinatizadeh, A.A.L., A.R. Mohamed, G.D. Najafpour, M. Hasnain Isa, H. Nasrollahzadeh., 2006. Kinetic Evaluation Of Palm Oil Mill Effluent Digestion In A High Rate Up-Flow Anaerobic Sludge Fixed Film Bioreactor. Process Biochemistry 41 (2006) 1038-1046. 